Slađana R. Mušikić ${ }^{l}$

Marija N. Marčetić

Slobodan Đ. Đurović

Business School of Applied Studies, Belgrade, Serbia
SCIENTIFIC REVIEW ARTICLE

DOI:10.5937/ekonomika1702079M

Received: April, 16, 2017

Accepted: May, 08, 2017

\title{
THE ROLE OF THE ACTIVE POLICY OF THE LABOR MARKET IN THE REPUBLIC OF SERBIA
}

\begin{abstract}
By joining the labor market, each individual acquires economic and working independence. The therefore, dealing with the issue of unemployment is one of the key topics. For the economy of one country the efficient functioning of the labor market represents a precondition for a successful implementation of structural reforms and even economic growth and development. The policy of the labor market is a sector policy which affects the labor market. It consists of the labor market could be described as one of the most important policies of the labor market. In the paper the author presents the role of the measures of the active policy of the labor market, tendencies and effects of the implementation of the measures of the active policy. Using the sources of the National Employment Service on the measures, programs, users and allocations for the active policy of the labor market, the author presents the role and results that the active policy of the labor market has in our country. The aim of the paper is to define the guidelines for a better harmonization of the supply and demand in the labor market by monitoring the implementation of the measures of the labor market.
\end{abstract}

Key words: the labor market, unemployment, the active policy of the labor market.

JEL classification: J21, J6, J 680

\section{УЛОГА АКТИВНЕ ПОЛИТИКЕ ТРЖИШТА РАДА У РЕПУБЛИЦИ СРБИЈИ}

\begin{abstract}
Апстракт
Кроз укључивање на тржиште рада сваки појединац стиче економску и радну самосталност тако да је решавање проблема незапослености једно од водећих питања. За привреду једне земље ефикасно деловање тржишта рада је предуслов успешног спровођењ а структурних реформи и равномерног привредног раста и развоја. Политика тржишта рада је секторска политика којом се делује на тржиште рада. Она се састоји од законодавства, активне политике тржишта рада и пасивне политике тржишта рада. Активна политика тржишта рада се може издвајити као једна од најбитнијих политика тржишта рада. У раду се приказује улога мера активне политике тржишта рада, тендениије и ефекти спровођења мера активне политике.
\end{abstract}

${ }^{1}$ sladjana.musikic@vpskp.edu.rs

${ }^{2}$ marija.marcetic@vpskp.edu.rs 
Полазећи од извора Националне службе за запошьавање о мерама, програмима, корисницима и издвајањима за активну политику тржишта рада приказује се коју улогу и резултате има активна политика тржишта рада у нашој земьи. Циљ рада је да се кроз праћење спровођења мера тржсишта рада дефинишу смернице за боље усклађивање понуде и тражне на овом тржишту.

Кључне речи: тржиште рада, незапосленост, активна политика тржишта рада.

\section{Introduction}

The policy of employment includes all aspects of economic policy which influence the usage of the working environment directly or indirectly. The policy of employment includes fiscal policy, monetary policy, the policy of salaries, the policy of external trade, the policy of foreign exchange course (Aradarenko, 2013). The joint part of the policy of employment is the policy of labor market. Its aim should be increasing the labor market trade by setting the balance between the offer and the search for the working force. The important growth of the unemployment among the countries which are in the transition made many countries getting the special programs of employment based on the concepts of (Active Labor Market Policies - ALMP). One of the aims of such policy is to make (un)employed more flexible compared to the request of the labor market and to give them the opportunity for improving their chances in order to find or keep their labors (Larsen, 2005).

ALMP supports creating the employment on two ways:

- Directly, by opening new working positions (public works, opening companies, subventions for the employment of new workers)

- Indirectly, by improving the employment (practice, training, efficient labor exchanges that provide better information of the labor market) (Lekovic \& Marjanovic, 2011).

In the OECD report from 1993, active policies of the labor market are formed in three groups, the first one relating to the mobilizing of the work force offer, and growth of the labor seeking (subvention creating of the new labors and micro-credit schemes, public works, subvention earnings), then the group of active measures that directly contribute to the knowledge improvement and the improvement of the labor market participants (the training programs for the unemployed, especially of the elderly people and of those who are under the risk of unemployment) and intercession in the aim of employment, connecting the offer and demand in the ALPM (OECD, 1993a).

The aim of this work is to show ALMP and their role fighting the employment, with special attention on the role of active labor market policy in the Republic of Serbia. The work consists of four parts. In the first part - the importance and the development of ALMP are shown. In the second part we deal with the theoretical and empirical consideration of this area. In the third part we deal with the institutional frameworks of ALMP trade market in Serbia. There are also analysis of the active measures trough its example of the national action plan. The works end on the basic conclusions. 


\section{Theoretical and empirical approach to the active measures}

The countries which first introduced the active measures are: Sweden, Norway, Denmark, Germany, The Netherlands and Belgium (Larsen, 2005; Mailand, 2005), and later that approach slowly spread in other European countries. This approach of employment became the constitutional part of the employment policy of European union in 1990s (European commission, 1993). Because of the growing unemployment - the concept of active participation on the labor market becomes one of the common priorities (Ballester, 2005;Schomann, 1995).

When we talk about achieving balance in the labor market it is necessary to point out, from the above, the Danish model of flexibility in the active employment policy, the so-called model "golden triangle" (Madsen, 2005). The goal of this model is to promote employment opportunities rather than job security ie. permanent employment. The first side of the "golden triangle" are flexible rules of employment, where employers facilitate dismissal in recession. About $25 \%$ of workers in the Danish private sector change job each year. At the same time (the other side of the triangle) there is a generous provision for unemployment in the amount of $90 \%$ of the minimum wage. The third side of the triangle is ALMP, effective system to help the unemployed. Denmark spends about $1.5 \%$ of GDP to ALPM (The official website of Denmark, 2017), while the amount in Serbia is about $0.1 \%$ of GDP (NSZ, 2016).

The theoretical concept of implementation of ALPM is presented by the "Beveridge curve". This graphical representation explains the relationship between unemployment and the job vacancy rate. The curve has a hyperbolic shape and slopes are downwards explaining that the higher unemployment rate comes with a smaller number of vacancies. The curve is dynamic, ie. for the given level of vacancies the growth of unemployment is expected, which implies the inefficiency of the labor market. Thus, the labor market is inefficient because it does not adequately perform the pairing process between job vacancies and inactive workforce. The following analysis show the displacement in the "Beverige curve": OECD (1993b); Katz (1994); Calmfors (1994).

It is necessary to highlight that the empirical studies mainly deal with the problems of ALMP on the labor market in the specific countries and that the extensive comparative studies are rare. Evaluation of active measures has demanding methodology. At the same time we must take into account the specificity of the country in which the assessment is conducted involving the questions of the level of economic development, labor market trends and the influence of state regulation in the labor market (Zubović, 2011). Also, it is necessary to consider a longer period of time in order not to get over-estimated effects results. Further more, it is necessary to take into account whether intervention is justified or not, the concept of evaluation methods (macro approach or mikro-evaluation) and the effects of active measures.

It is necessary to highlight that the empirical studies mainly deal with the problems of ALMP on the labor market in the specific countries and that the extensive comparative studies are rare. Summary results of the evaluation of active measures is given in Bono (2010); Boeri \& Ours (2008); Caliendo (2006); Betcherman and others (2004, 1999) for developed countries. The evaluations that deal with problems ALPM in transition countries are: Ognjenovic (2011); Bonin \& Rinne (2006); Betcherman, Olivas \& Dar (2004); Spevachek (2009), Lehman \& Kluve (2010), and many others. The last mentioned study (Lehmann \& Kluve, 2010) shows that there is a positive impact of active measures, given the relative level of expenditure for ALPM in relation to GDP, to the reduce of the unemployment rate. The other studies that examine the relation between the unemployment rate and expenses for the active measures are (Katz, 1994; Calmfors, 
1994; Martin 2000; OECD 1993c; etc). The study of Forslund et al. (2011) concluded that, depending on the phase in the economic cycle, different programs have different effects. In the period of recession programs training the most influence on the shortening of the time to find work. One of the elements that adversely affect the effects of the application of active measures are national employment services that in most transition countries, including Serbia, are not sufficiently effective when it comes to implementing active policies. The reason for this is the limited number of advisers who work directly with persons in need of assistance in employment. (Kuddo, 2009).

\section{Institutional framework of the active policy on the labor market of the Republic of Serbia}

Nowadays Serbia is in the situation which many transitional countries of Eastern and South - East Europe have passed or are still passing through. The rate of unemployment lays behind the Lisbon's aim (employment from $70 \%$ ), and the rate of unemployment, based on the official information, shows that each fifth able-bodied citizen is unemployed. In accordance with it, one of the consequences of transitional movements is strengthening the public interventions on the labor market. Apart from the passive measures which are continually being done, in 2005. started intensive usage of active measures.

Serbia actively started implementing the labor market policy through giving higher importance of the active measures. In 2005. the National strategy of employment was adapted for the period 2005-2010. Three main principles based on the new national strategy of employment from 2011. to 2020 are: increasing the employment, investing in the human capital and social inclusion (Ministry of Economic and Regional Development, 2010). New strategy also follows the priorities of the European strategy- Europe 2020 in the field of employment (European commission, 2010). Actually the European strategy in the field of employment intrudes three integrated guidelines that refer to: the growth of the participation on the labor market and decrease of structural unemployment, the development of the qualified work force as a response to for the needs of the labor market, promoting the quality of life and endless learning, improving the performance of the education system and increasing the participation of tertiary education, as well as promoting social involvement and dealing with the poverty.

Business contractors of employment at the labor market in the Republic of Serbia are the National Employment Service (as the public service) and the Employment Agency (which are involved in the law system from 2003). The surveillance over the work of National Employment Service is done by the Ministry of Economic and Regional Development. Employment agencies can be founded by legal and physical person.

Ascertaining the work of the National Employment Service and following the efficiency of implementation of ALPM from the action plan is determining by the agreement of performance concluded by the Minister competent for the labor hiring and the director from the National Employment Service. National Employment Service gives the quarterly, half yearly and yearly reports about the work to the Minister and those reports are then forwarded to the Government. Also, the Ministry sends to the Government yearly report about the conduction of the action plan, at least till April 30, for the previous year.

In Serbia, the Law on Employment and Unemployment Insurance provides that the monitoring and evaluation of the effects of ALPM is a set of activities aimed at monitoring the implementation of plans, programs and measures of ALPM, intesifyng developments of the labor market, in order to create conditions for undertaking measures aimed at its improvement (Aksentijević, 2011). 


\section{Active employment measures in the Republic of Serbia}

ALPM are aimed at improving the employment, carried out by the National Employment Service, and they are:

1. Mediation in employment of labor seekers is organized to accelerate the process of connecting employers and the unemployed. These include: consultation focused on the selection of appropriate labors, developing skills of active labor search, establishing contacts with employers and satisfying expressed needs, selection and deployment of the unemployed person to the employer for employment or other work opportunities, organizing trade fairs etc.

2. Vocational guidance and counseling on career planning is done through: information and advice about the opportunities for career development; psychological assessment for the purposes of employment, participation in programs of additional education and training and entrepreneurship programs; training self-efficacy, workshops for coping with stress caused by labor loss, psychological support workshops for career planning (for potential redundancies), the organization of trade fairs for professional orientation, participation in other events related to career planning and so on. These measures are associated with lower cost compared to other active measures and contribute to shortening the period of unemployment. National Employment Service provides training through donor projects in cooperation with the Ministry in charge of employment.

3. Employment subsidies for new job creation are granted to employers in the private sector in a lump sum. Employers who belong to the private sector, especially SME's, can have subsidies for employing on new jobs employees who are in hardly employ category. Subsidy is paid to the employer as a lump sum, but the end-users of subsidies is unemployed persons who are employed through this measure. The unemployed who obtein work place with this measure, are simply replacing those who would be employed in a case this measures don't exists. The positive effects of this ALPM are diminished by the lost of those on whose place came the participants in the program, so there is a "dead" effect and effect of substitution. However, it offers the advantage for vulnerable young people to gain work experience, stay in touch with the labor market (Corbanese \& Gianni, 2009). To neutralize the negative effects, it is important to reshape the program.

4. Support for self-employment is the resources and technical assistance that can achieve the unemployed who is in process of self-employment. Self-employment is the establishment of shops, cooperatives, agricultural farms or the other forms of entrepreneurship of the unemployed, as well as the establishment of a company if it's based founder starts self-employment relationship. Promotion of self-employment involves two steps. First, counseling about what self-employing is, and what is needed to lead the business. The second step envisages the provision of package of measures to support training for entrepreneurship, business plan, financial support. Unemployed people can receive state grants (subsidies) to start their own business. The subsidy paid by the National Employment Service is the same for the whole country, and some local governments can have their own subsidy programs. Condition for receiving subsidies for self-employment is to carry out training of the National Employment Service (and other institutions) and write a business plan.

5. Further education and training programs provide an opportunity to the unemployed through the process of theoretical and practical training to acquire new knowledge and skills for employment or self-employment. 
Further education and training are organized by the National Service Agency or at the request of the employer or for the needs of the labor market. Training programs can be related to the increase in the willingness to work or to acquire specific skills. Training and retraining are directed primarily toward certain groups, as follows: long-term unemployed and young people.

6. Incentives for users of pecuniary for unemployed persons and the user of financial compensation for unemployment insurance gets for at least three months from the moment of recognition of the rights and enter into employment for an indefinite period which shall be entitled to one-time stimulus for employment in the amount of $30 \%$ of the total amount of money, benefits without contributions for compulsory social insurance, which would have been paid for the time remaining until the expiration of the right to financial compensation.

7. Public works as active programs are being implemented since 2006. Public works of interest for the Republic can be organized and implemented in cooperation with the territorial autonomy and local self-government, based on the contract, which defines the methods and sources of funding. Public works are carring out in the social, humanitarian, cultural activities, maintenance of public infrastructure, maintenance and protection of the environment and nature. Public works programs are primarily designed to support the less employable, long-term unemployed people in underdeveloped areas. The Government can implement these projects independently or in cooperation with the private sector and local government. Public works conducts an employer - contractor on the basis of a public competition. The cost of public works are: salaries of unemployed persons, reimbursement of expenses for traveling to and from work, reimbursement of cost of public works and charges of organizing training. Effects of public works are positive, but lacking long-term effects on employment.

8. ALPM for persons with disabilities, in order to encourage employment and measures, are implemented in accordance with the Law on professional rehabilitation and employment of persons with disabilities.

9. The co-financing programs of active labor market provided by local employment action plans (LEAP) from the state budget at the request of the autonomous region or a local authority. Autonomous region, or local government, can through the National Employment Service submitte a requirements for participation in the financing of programs of active labor market measures provided for LEAP.

10. Packages of services for unemployed persons who have priority for inclusion in ALPM indicate a need to intensify activities in order to improve position category of less employable persons, particularly young people, older and redundant workers, persons with no qualifications or low-skilled, long-term unemployed and people with disabilities (National action plan for 2007).

\section{Conclusion}

In terms of economic restructuring and adjustment to the needs of modern business, the burden of change are distributed unevenly. Most affected are less educated, young people without work experience and long-term unemployed. Well-designed, targeted and comprehensive programs of ALPM could contribute to a faster, easier and better inclusion of the unemployed into the labor market. Application ALPM is not sufficient in itself to 
increase employment, but need support of adequate industrial macroeconomic policies that attract investment, create and support the demand for profit. In the absence of a favorable macroeconomic environment, which will result in increased investment, economic growth and employment, ALPM can provide only temporary support to the unemployed.

Evaluation of the effects of ALPM should be an integral part of the planning in employment and education policy. Systematic approach should be implemented for the evaluation and application of ALPM in the Republic of Serbia. Only through a comprehensive analysis is possible to evaluate which measures successfully achieved its goal, which of them should be adjusted and improved, and which to discard. Allocation for ALPM in Serbia lag behind allocation of developed countries, while in comparison with countries in transition, structure of expenditures for ALPM is worse. In addition, it is important how these funds are spent and is it purposefully (OECD, 2016). It is also necessary to increase the volume of financial resources making the selection of potential participants to ALPM had a greater effect on employment, choose adequate measures, reinforce national employment services.

\section{Reference}

Aksentijević, S., (2011). Mere aktivne politike u Srbiji,, Tematski zbornik: Aktivne mere na tržištu rada i pitanje zaposlenosti, Institut ekonomskiih nauka, Beograd.

Arandarenko, M., Krstić, G., Golicin, P., Vujić, V., (2013). Studija: Procena uticaja politika u oblasti zapošljavanja, FREN, Beograd

Betcherman, G., Olivas, K., Dar, A. (2004), Impact of Active Labour Market Programs: New Evidence from Evaluations with Particular Attention to Developing and Transition Countries, Social Protection Disscusion Paper Series 0402, the World Bank, January 2004

Boeri, T., Ours, J. (2008). Active Labor Market Policies, pp. 255-276, The Economics of Imperfect Labor Markets, Princeton University Press, 2008. http://press. princeton.edu/chapters/s12_8771.pdf.

Bonin, H., Rinne, U. (2006). Evaluation of the Active Labor Market Program Beautiful Serbia, IZA Discussion Paper 2533, December 2006.

Caliendo, M. (2006). The German Labor Market and Active Labor Market Policies-A Brief Overview. Micro-econometric Evaluation of Labor Market Policies, 99-125.

Calmfors, L. (1994). Active Labor Market Policy and Unemployment: a Framework for the Analysis of Crucial Design Features, OECD Economic Studies 22, 1994.

Corbanese, V., Gianni, R.,(2009). Smernice za sprovođenje aktivnih mera zapošljavanja i traženja posla namenjenih ugroženim mladima, ILO,: (International Labor union), available at: http://www.ilo.org/wcmsp5/groups/public/---europe/---rogeneva/---sro budapest/documents/publication/wcms_169033.pdf

European Commission (2010). Europe 2020: European Strategy for Smart, Sustainable and Inclusive Growth. Retrieved January 27, 2017, fromhttp://eunec.vlor.be/ detail_bestanden/doc014\%20Europe\%202020.pdf.

Forslund, A.,Krueger, A.,(2011). What active labor market policy works in a recession, Retrieved January 27, 2017,fromhttp://econpapers.repec.org/paper/ hhssunrpe/2011_5f0009.htm 
OECD Economic Outlook, (2016). Retrieved January 12, 2017,from http://www. oecd.org/eco/economic outlook.htm

Katz L.F. (1994), "Active Labor Market Policies to Expand Employment and Opportunity", pp. 239-290, u Thematic collection: Reducing Unemployment: Current Issues and Policy Options, Wyoming-u (Jackson Hole) S.A.D., 25-27. august, 1994. http://kcfed.org/publications/research/escp/escp-1994.cfm

Kuddo, A. (2009). Employment Services and Active Labor Market Programs in Eastern European and Central Asian Countries, Social Protection Disscusion Paper0918, the World Bank, October 2009.

Larsen, F. (2005), Active Labor Market Policy in Denmark as an Example of Transitional Labor Market Flexicurity Arrangements, Employment Policy from Different Angles, Bredgaard, T., Larsen, F. (ur.),DJØF Publishing, pp. 115-133, Copenhagen, 2005.

Lehmann, H., Kluve, J. (2010). Assessing Active Labor Market Policies in Transitional Economies, The Labor Market Impact of the Eu Enlargement, Caroleo, F.E., Pastore, F. (ur.), Springer-Verlag Berli Heidelberg, pp.275-307,

Leković, V., Marjanović,G. (2011). Regulatorni aspekti i reforme na tržištu rada, Tematski zbornik: Aktivne mere na tržištu rada i pitanje zaposlenosti, Institut ekonomskih nauka, Beograd.

Madsen, K.P. (2005).The Danish Road to 'Flexicurity' Where Are We? And HowDid We Get There?, pp. 269-289, Employment Policy from DifferentAngles, Bredgaard, T., Larsen F. (ur.), DJØF Publishing, Copenhagen, 2005.

Mailand, M. (2005).The Involvement of Social Partners in Active Labour Market Policy - do the Patterns fit Expectations from Regimes Theories?, Employment Policy from Different Angles, Bredgaard, T., Larsen F. (ur.), DJØF Publishing, pp. 135-151, Copenhagen.

Martin, J.P. (2000). What Works Among Active Labour Market Policies: Evidence from OECD Countries' Experiences, OECD Economic Studies 3, OECD Publishing.

Nacionalna služba za zapošljavanje,Retrieved January 12, 2017, from:http://www. nsz.gov.rs/live/digitalAssets/5/5092_sporazum_o_u_inku_nsz_za2016.pdf

Nacionalni akcioni plan za 2017, Retrieved Mapch 12, 2017, from:http:// socijalnoukljucivanje.gov.rs/wp-content/uploads/2017/01/Nacionalni-akcioniplan-zaposljavanja-za-2017.-godinu.pdf

OECD (1993). Active Labour Market Policies: Assessing Macroeconomic and Microeconomic Effects, pp.. 39-79, Employment Outlook, OECD: Paris.

Ognjenović,K., (2011). Regulatorni aspekti i reforme na tržištu rada, Tematski zbornik: Aktivne mere na tržištu rada i pitanje zaposlenosti, Institut ekonomskih nauka, Beograd.

Spevacek AM (2009). Effectiveness of Active Labor Market Programs: A review of Programs in CEE and CIS, USAID knowledge service center, http://pdf.usaid. gov/pdf_docs/Pnadm044.pdf

The official website of Denmark, Retrieved Mapch30, 2017,from:

http://denmark.dk/en/society/welfare/flexicurity

Zubović, J.,(2011). Aktivne mere na tržištu rada i evaluacija uticaja, Tematski zbornik: Aktivne mere na tržištu rada i pitanje zaposlenosti, Institut ekonomskiih nauka, Beograd. 